\title{
Evaluation of the Biochemical Composition of Four Marine Algae and Its Nutritional Value for Brine Shrimp.
}

\author{
Cordilea Hannah $^{1 \& 2}$, Mathumathi Mani ${ }^{2}$ and Rengasamy Ramasamy ${ }^{2}$ \\ ${ }^{I}$ Dept. Plant Biology \& Plant Biotechnology, Women's Christian College, Chennai-600006, INDIA; \\ ${ }^{2}$ Center for Advanced Studies in Botany, University of Madras (Guindy campus), Chennai - 600 025, INDIA.
}

\begin{abstract}
Microalgae are utilized in aquaculture as a live feed for the crustaceans, ablone, zooplanktons, etc. The present study was aimed to examine the nutritional status of Artemia sp. nauplii enriched with four different algal sources namely Chaetoceros calcitrans, Skeletonema coastaum, Duniella salina \& D. bardawil and also the amount of beta-carotene assimilated when enriched with the two green algae. Artemia sp. nauplii enriched with D. salina showed high amounts of protein and carbohydrate, whereas Artemia sp. fed with Chaetoceros calcitrans showed high amounts of lipid. The protein profile of Artemia sp. enriched with different algal sources did not show prominent differences in the polypeptide bands. However, high amount of beta-carotene was assimilated in Artemia sp. nauplii when enriched with D. salina. Hence this study showed that the microalgae D. salina can be used as a potential feed to improve the nutritional status of Artemia sp. nauplii.
\end{abstract}

Keywords: Microalgae, nutritional status, Artemia sp., beta carotene.

\section{Introduction}

Aquaculture is becoming a major system for augmenting animal production, to supplement the stagnating marine fish production and to compensate the growing uncertainties of marine resource sustainability (Sankar and Ramachandran, 2002). Hence developing new technology, new breeds and newly domesticated breeds of fishes and live feeds offer a great hope for the future with a promise for blue revolution in the century to match the green revolution (Bernado, 2003). The first feeding of any cultivable organism is the most "critical phase' of their life when they need the right type of nourishment for their survival and growth. Live diets include three groups of organisms namely phytoplankton such as microalgae $(2-20 \mu \mathrm{m})$ and zooplankton such

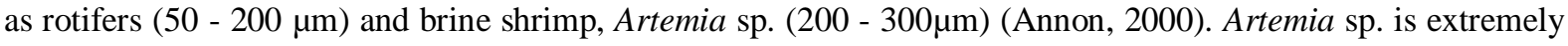
important as a standard live feed for over $85 \%$ of marine species (Kinne, 1977). Artemia sp. is a biologically uncontaminated readily available and acceptable larval feed (Takami, 1993; Reddy \& Thakur, 1998), possessing several features such as: small size, easy ingestion (Lèger et al., 1986), high nutritional value, unchanging food requirement from nauplii to adult (Helfrich, 1973) and high tolerance to various culture environments (Lèger et al., 1987). Moreover they also can be used as biovehicles by which the nutritional components can be administered to the fish and shrimp larvae. This phenomenon is known as bioencapsulation of live food organisms (Tamaru et al., 2000). Microalgae which are at the base of the food chain represent the third largest aquacultured crop in the world (Hanisak, 1998 \& Annon 2000). In nature, most fishes and shrimps feed on varied types of natural phytoplanktons and zooplanktons. Farming of marine animals, including both finfish and invertebrates - chiefly crustaceans (shrimps) and mollusks requires microalgae as feed at some point in the life cycle (Jeffrey et al., 1994). However microalgae are also used widely to improve the nutritional content of zooplankton live feeds by allowing the zooplankton to fill their digestive systems with microalgae before subsequently being fed to the fish or shrimp larvae. In this "conditioning" strategy the zooplanktons serve as bags of appropriate size that partially digest the algae and stimulate components to the larvae. The green algae Dunaliella, produces abundant $\beta$-carotene (Wikifors, 2000) (an accessory light harvesting pigment) (Glazer, 1983). Carotenoids contribute to the health and reproduction in fishes, as well as their pigmentation. It is well documented that crustaceans are unable to biosynthesize carotenoids and therefore, the carotenoids are included in the feed and fed to fishes and shrimps through Artemia sp. nauplii. The aim of this present study is to explore the nutritional evaluati of Artemia sp. nauplii enriched with different algal sources.

\section{Materials And Methods}

The algal cultures of the diatoms: Chaetoceros calcitrans and Skeletonema coastaum and the green algae: Dunalliella salina and D. bardawil were obtained from the Algal Culture Collection at the Center for Advanced Studies in Botany, University of Madras. The diatoms were maintained in F/2 medium (Guillard and Ryther, 1962) and the green algae were maintained in De Walne's medium. 


\section{Hatching of Artemia cysts}

The cysts of Artemia sp. obtained from the Department of Zoology, University of Madras, were used for this investigation. Artemia cysts were hatched as per the standard procedure outlined by Sorgeloss et al., 1986. The hatched nauplii from the decapsulated cysts (more than $90 \%$ Instar - I) were siphoned out and used for the enrichment experiments.

\section{Enrichment of Artemia nauplii}

The $24 \mathrm{~h}$ old 600 nauplii in $1 \mathrm{~L}$ of seawater were fed separately with the microalgae viz; Cheatoceros calcitrans (22nd day), Skeletonema coastatum (20th day), Dunaliella salina (15th day) and D. bardawil (21st day) (obtained from the Centre for Advanced studies in Botany, University of Madras) at different cell concentrations viz; $50-70$ cells $/ \mathrm{mL}, 30-60$ cells/mL, $30-80$ cells $/ \mathrm{mL}, 40-90$ cells $/ \mathrm{mL}, 20-80$ cells $/ \mathrm{mL}$ and $50-100$ cells $/ \mathrm{mL}$ respectively. The experiment was conducted for a period of $24 \mathrm{~h}$. Every $3 \mathrm{~h}$ interval the animals were observed under microscope and recorded their gut region. The collected nauplii are washed in fresh water and their nutritional status was evaluated.

\section{Biochemical Analysis}

Fifty mg fresh weight of the Artemia nauplii enriched with different algal sources were taken and estimated for different biochemical constituents. The total protein was quantified following the method of Bradford, 1976. The total carbohydrate was estimated as per the method of Dubois et al., 1956.The total lipid was determined using the method of Jordifolch lees, 1956. SDS-PAGE was carried out using the modified method of Laemmli (1970). The Artemia sp. nauplii enriched with the four different microalgae were studied for its carotenoid content by following the method of Schwartz and Patroni-Killam (1985). The amount of carotenoids extracted were scanned under UV visible spectrophotometer at $450 \mathrm{~nm}$ and further confirmed by TLC. All the values were given on wet weight basis, with three replications. The values were analyzed using oneway ANOVA by the Agres statistical software package.

\section{Results and Discussion}

In the present study, four different microalgae were used as feed to live Artemia sp. The protein, lipid and carbohydrate content of four different algal sources were estimated. Among the four algal sources used to enrich Artemia sp., Dunaliella salina showed high amount of protein content $(69 \mu \mathrm{g} / \mathrm{ml})$ followed by $D$. bardawil, Chaetoceros calcitrans and Skeletonema coastatum . as shown in figure (1). Dunaliella salina enriched nauplii showed high content of carbohydrate $(189 \mu \mathrm{g} / \mathrm{ml})$ followed by Chaetoceros calcitrans, Skeletonema coastatum and D. bardawil (Fig. 3). However high lipid content was recorded in the Artemia nauplii enriched with Chaetoceros calcitrans(Fig. 2). The above results are in similar to the findings of D'souza (1999) who reported that Penaid larvae fed with Chaetoceros sp. showed high protein and lipid content. The protein profile using the SDS-PAGE of Artemia sp. enriched with different algal sources did not show prominent differences in the polypeptide bands as well as when compared the control (Fig 6). The beta- carotene extracted from Artemia sp. nauplii enriched with D. salina $(1.66 \mu \mathrm{g} / \mathrm{ml})$ as shown in figure 4 and D. bardawil $(0.94 \mu \mathrm{g} / \mathrm{ml})$ showed a peak at $450 \mathrm{~nm}$. The extracted beta-carotene was subjected to TLC showed an Rf value (0.85) similar to the authentic beta-carotene (Fig. 5). Our present findings are in congruent with Boonyaratpalin et al. (2001), who reported that the Artemia nauplii enriched with $D$. salina contained beta-carotene, this nauplii when fed to the shrimps imparted colouration. The Artemia sp. enriched with beta-carotene via the algal source serves as bioencapsulator where it can be transferred up the food chain as many crustaceans are unable to synthesize carotenoids de novo (Goodwin, 1984) and moreover the microencapsulated live diets enhanced the growth and survival of shrimps and fishes (Pedroza, et al. 2004). Carotenoids not only impart coloration but also improve tolerance to stress conditions and the immunity of aquatic animals (Hunter, 2000, Supamattaya et al., 2005). It has been shown that Penaeus monodon showed enhanced resistance to white spot syndrome viral infection when fed with diet enriched with D. salina (Madhumathi \& Rengasamy, 2011), which is rich source of carotenoids.

Therefore a good selection of algal species is a prerequisite to support the aquaculture industry inorder to improve nutritional quality, healthy growth and hatchery efficiency. Hence it could be concluded from the present study that among the four microalgae tested $D$. salina could be used as a potential live feed to improve the nutritional status of Artemia sp. nauplii. 
Figure 1:

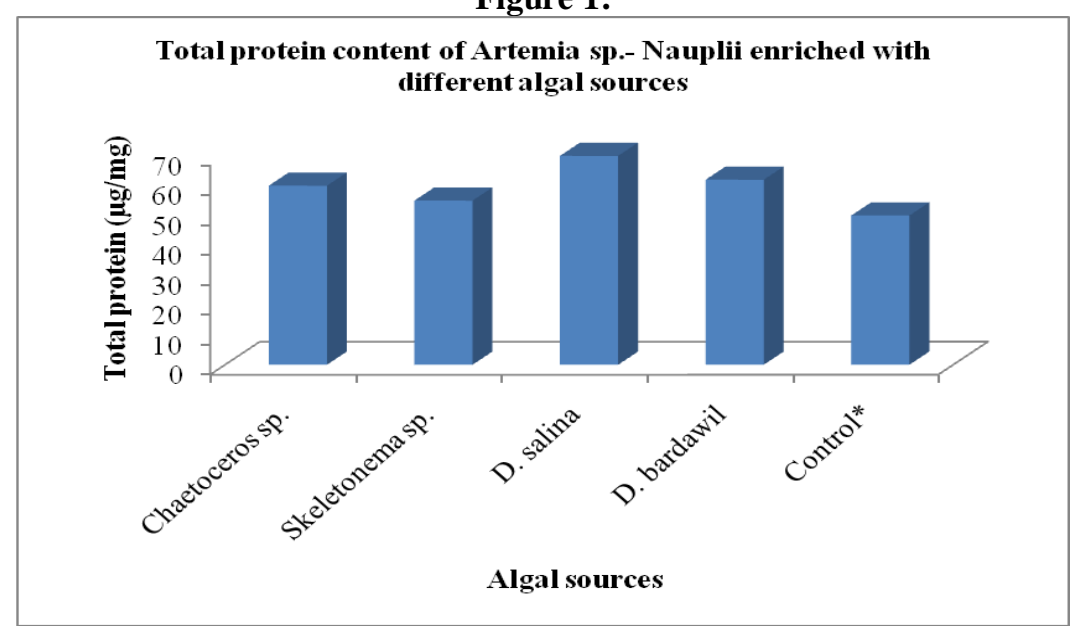

Figure 2:

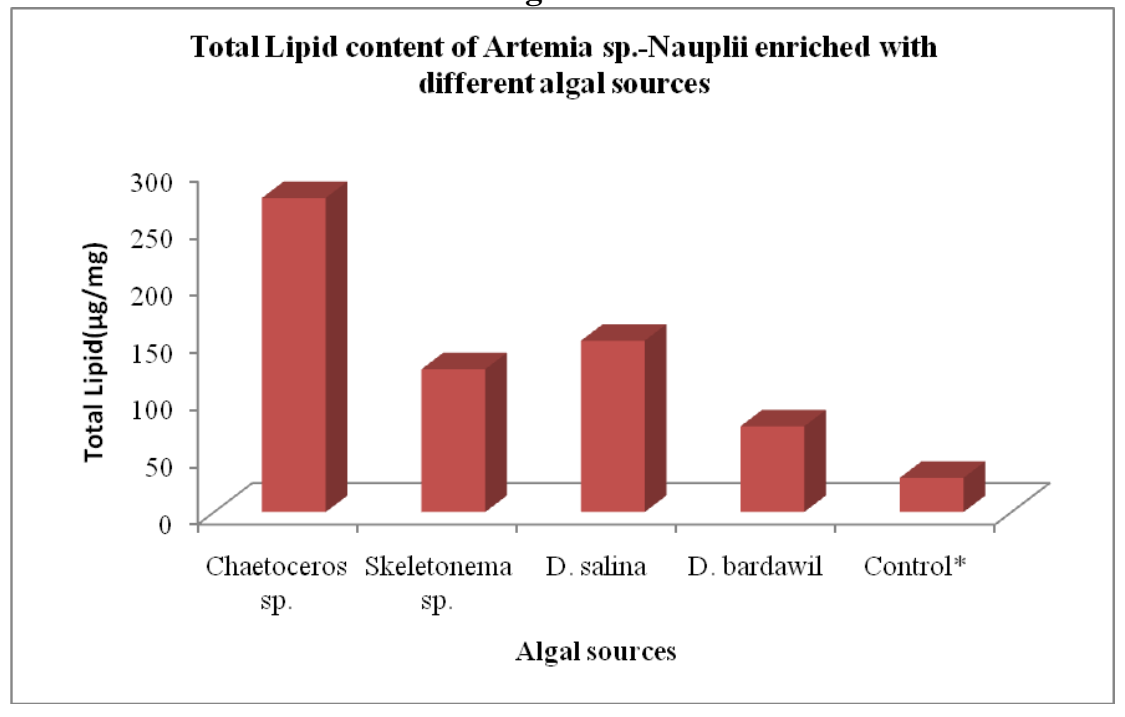

Figure 3:

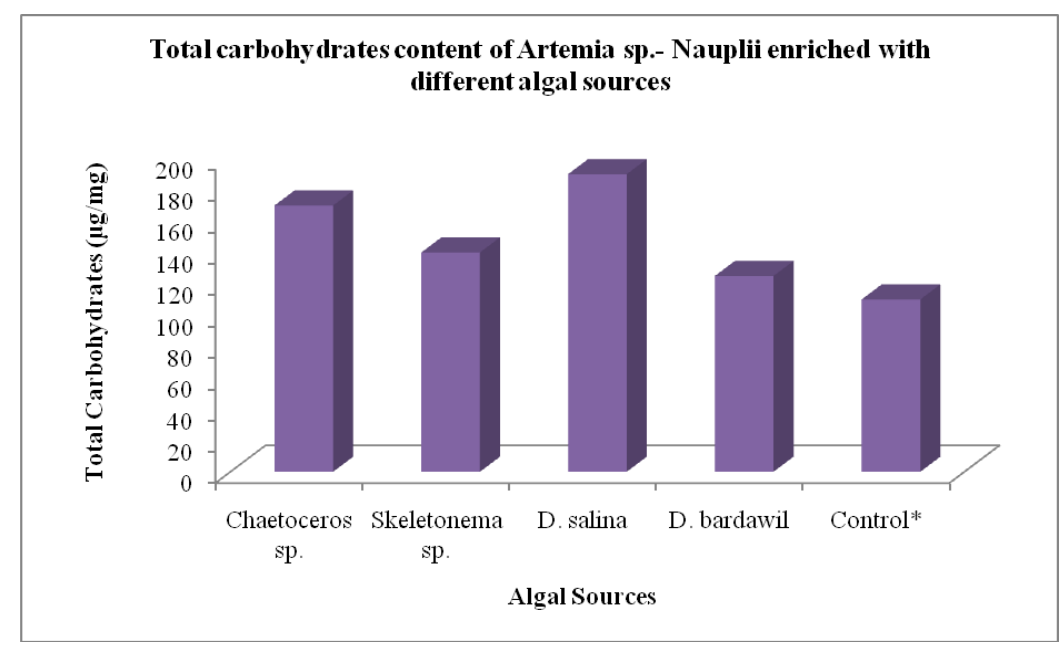




\section{Figure 4:}

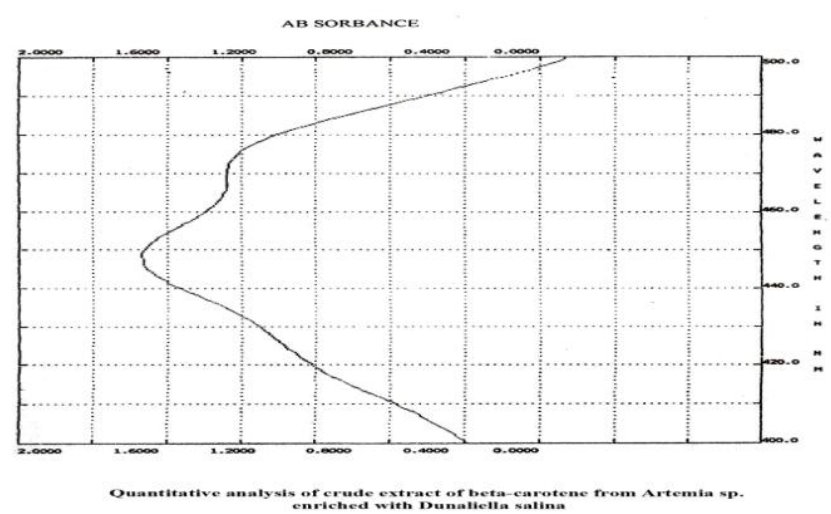

Figure 5:

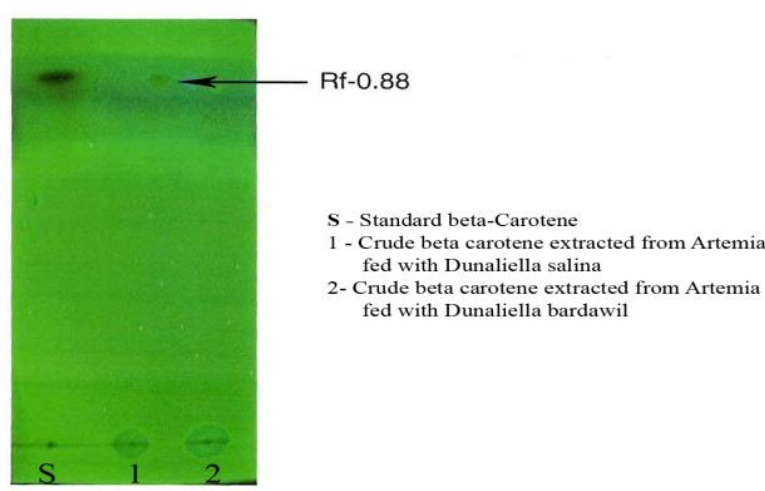

Qualitative analysis of crude extract of beta-carotene from Artemia sp. (Thin layer chromatography under UV Light)

Figure 6:

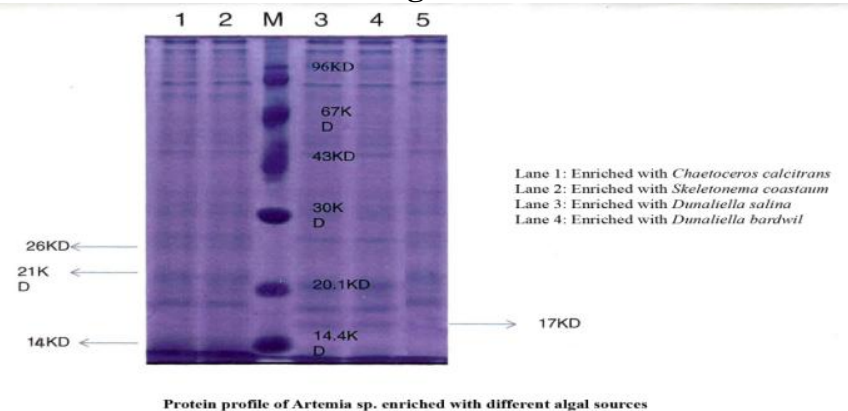

\section{Reference}

[1]. Annon. 2000. The state of world fisheries and aquaculture. Food and agriculture organisation of the United Nations, Rome, Italy. pp: 142.

[2]. Bernado, B. 2003. Feature Article: the promise of blue revolution. Aquaculture magazine, 29 - 36.

[3]. Boonyaratpalin, M. S., Thongrod, K., Supamattaya, G., Britton.and L.E Schlipaulis. 2001. Effect of $\beta$ - carotene source, Dunaliella salina, and astaxanthin on pigmentation, growth, survival and health of Penaeus monodon. Aquaculture research.32: 182- 190.

[4]. Bradford, M. 1976. A rapid and sensitive method for the quantification of micro quantities of protein utilizing the principle of protein binding. Analytical Biochemistry. 72: 248-254.

[5]. D'Souza, F.M.L. 1999. The nutritional value of microalgae to penaeid prawn larvae. PhD Thesis, Queensland University of Technology, Brisbane. pp. 199.

[6]. D'souza, F.M.L. and Loneragan, N.R. 1999. Effects of monospecific and mixed algae diets on survival, development and fatty acid composition of penaeid prawn (penaeus spp.) larvae. Marine biology. 133: 621-633. 
[7]. Dubois, M.K., Hamilton, T., R.A. Robeus. and F. Smith. 1956. Calorimetric method for determination of sugars and related substances. Analytical chemistry. 28: 350-356.

[8]. Glazer, A.N. 1983. Comparative biochemistry of photosynthetic light-harvesting systems. Annual Review of Biochemistry. 52:125157.

[9]. Goodwin, T.W. 1984. The Biochemistry of the Carotenoids, $2^{\text {nd }}$ (Ed.), Chapman and Hall., London. pp. 64-96.

[10]. Guillard, R.R.L. and J.H. Ryther. 1962. Studies of marine planktonic diatoms I. cyctotella Husted, Canadian journal microbiology. 8: 229-239.

[11]. Hanisak, M.D., 1998. Seaweed cultivation: global trends. World Aquaculture, 29: 18- 21.

[12]. Hunter, B. 2000. Physiological functions of astaxanthine and other carotenoids in marine organisms. In: Sungpuang, P. (eds.), FirstSouth East Asia and Pacific Regional meeting on carotenoids, Mahidol University, Bangkok, 2-5, 19 p.

[13]. Jeffrey, S. W., Brown, M.R. \& Garland, C.D. 1994. Microalgae for Mariculture. Csiro Dvision of Fisheries, Hobart, Tasmania, Australia. pp. 79.

[14]. Jordifolch lees, M. 1956. A simple method for isolation and purification of lipid, general procedure. Journal of Biological chemistry. 226: $497-507$.

[15]. Kinne, O. 1977. Research cultivation in manure ecology, Kinne,O. (eds.), Vol.3. part 11. Wiley interscience, Newyork. pp. $579-585$.

[16]. Laemmli, U.K. 1970. Clevage of structural proteins during the assembly of the head of bacteriophage T4. Nature, $227: 680-685$.

[17]. Lèger, P., Bengtson, D.A., Simpson, K.L. and Sorgeloos, P. 1986. The use and the nutritional value of Artemia as food source. In oceanography and marine biology. Annu. Rev., 24: 521-631.

[18]. Lèger, P., Bengtson, D.A., Simpson, K.L., Sorgeloos, P. and Beck, A.D. 1987. The nutritional value of Artemia: a review. Ecology, Culturing, Use in Aquaculture, $3: 357$ - 372.

[19]. Madumathi, M and Rengasamy R. 2011. Antioxidant status of Penaeus monodon fed with Dunaliella salina supplemented diet and resistance against WSSV. International Journal of Engineering Science and Technology (IJEST) 3 (10) : 7249 - 7260.

[20]. Pedroza-Islas, R., Gallardo, P., Vernon-Carter, E.J., Garcia-Galano, T., Rosas, C., Pascual, C. and Gaxiola, G. 2004. Growth,survival, quality and digestive enzyme activities of larval shrimp fed microencapsulated, mixed and live diets. Aquac. Nutr. 10:167-173.

[21]. Reddy, A.K. and Thakur, N.K. 1998. Artemia the most widely used live food for aquahatcheries, Training Manual, Mumbai, CIPE, pp 111.

[22]. Sankar, T.V. and Ramachandran, A. (2002). World fish production: The growing importance of aquaculture. Fishing Chimes, 22(5): 21-24.

[23]. Schwartz, S.J. and Patroni-Killam, M. 1985. Detection of cistrans carotene isomers by two-dimensional thin layer and high performance liquid chromatography. J. Agric. Food Chem. 33: 1160-1163.

[24]. Sorgeloss, P., Bossuyt, E., Baeza-Mesa, M. and Persoone, G. 1986. Decapsulation of Artemia cysts: a simple technique for the improvement of the use of brine shrimp in aquaculture. Aquaculture. 12: 311-316.

[25]. Supamattaya, K., Kiriratnikom, S., Boonyaratpalin, M. and Borowitzka, L. 2005. Effect of a Dunaliella extract on growth performance, health condition, immune response and disease resistance in black tiger shrimp (Penaeus monodon). Aquaculture. 248: 207-216.

[26]. Tamura, C.S., Pnag, L. and Ako, H. 2000. Effects of three maturation diets on spawning of the armored catfish (Corydoras aenus). Aquatips. Reg. Notes. Cent. Trop. Subtrop. Aquac. 11(3): 4-6.

[27]. Wikifors, G.H. 2000. Microalgal culture. In: Stickney, R.R. (Eds.) Encylopedia of Aquaculture. John wiley and sons, New York. pp. 520-525. 